\title{
Experience with cellulose acetate-coated activated charcoal haemoperfusion in the treatment of severe hypnotic drug intoxication
}

\author{
Peter Crome \\ M.D., M.R.C.P. \\ BRIAN WIDDOP
}

\author{
GERHARDT HAMPEL \\ M.D. \\ RoY GOULDING \\ B.Sc., M.D., F.R.C.P., F.R.C.Path.
}

Poisons Unit, Guy's Hospital, London SE1 7RT

\begin{abstract}
Summary
A haemoperfusion column containing activated charcoal coated with cellulose acetate was used to treat 7 patients with barbiturate or ethchlorvynol poisoning. Six of the patients showed marked lightening of coma and all showed a significant fall in plasma drug concentration. Plasma drug clearance and platelet loss were similar to those reported for other coated charcoal columns. Cellulose acetate-coated charcoal haemoperfusion may reduce the period of coma in severe poisoning with barbiturates and other hypnotic drugs and thus the morbidity and mortality.
\end{abstract}

\section{Introduction}

In England and Wales, the mortality from drug poisoning amongst those patients admitted alive to hospital is less than $1 \%$. However, if only severely intoxicated patients are considered a different pattern emerges, with mortality rates of $14 \%$ (Volans et al., 1977) and $21 \%$ (Hampel and Widdop, 1978) being reported in 2 recent studies. For such patients, extra-corporeal haemoperfusion may reduce the period of coma and hence morbidity and mortality.

The original haemoperfusion devices contained uncoated activated charcoal. Although effective in removing the drug from the circulation, unacceptable side effects of thrombocytopenia, fibrinogen loss and pyrogen reactions were observed (Yatzidis et al., 1965). Various protective coatings have therefore been applied to the charcoal particles in order to make the systems more bio-compatible. The authors have used one such device with an acrylic-hydrogel as the coating system and another in which the uncoated charcoal particles have been attached to a fixed-bed (Vale et al., 1975a; Volans et al., 1977; Hampel and Widdop, 1978). This paper describes an experience in treating patients with a third type of charcoal haemoperfusion column in which the particles are coated with cellulose acetate.

\section{Patients and methods}

Patient selection

As in the other series (Vale et al., 1975a, 1975b; Volans et al., 1977; Hampel et al., 1980) patients were selected for treatment on the basis of clinical features of severe intoxication in the presence of high plasma drug concentrations. These clinical criteria can be subdivided into (a) severe poisoning (Grade IV coma, respiratory depression, hypotension); (b) prolonged coma with complications such as pneumonia; and (c) suspected brain death following a cardiac or respiratory arrest.

In all cases a full toxicological screen was performed before haemoperfusion, and quantitative plasma assays by specific gas-chromatographic methods were carried out for those drugs which were detected.

\section{Haemoperfusion techniques}

An arterio-venous shunt was fashioned between the radial artery and a suitable forearm vein. Skin incisions were kept small in order to minimize bleeding. The patient then received an i.v. injection of 10000 units of heparin followed by a continuous infusion adjusted to produce a plasma heparin concentration of $2 \mathrm{u}$./ml. The patient's blood was pumped through a 300-g cellulose acetate-coated charcoal column (Adsorba 300C, Gambro Ltd, Hechingen, West Germany) which had been flushed with one litre of saline containing 1000 units of heparin. At the end of haemoperfusion, heparinization was reversed by an i.v. injection of protamine sulphate. Blood flows of $150-300 \mathrm{ml} / \mathrm{min}$ were 


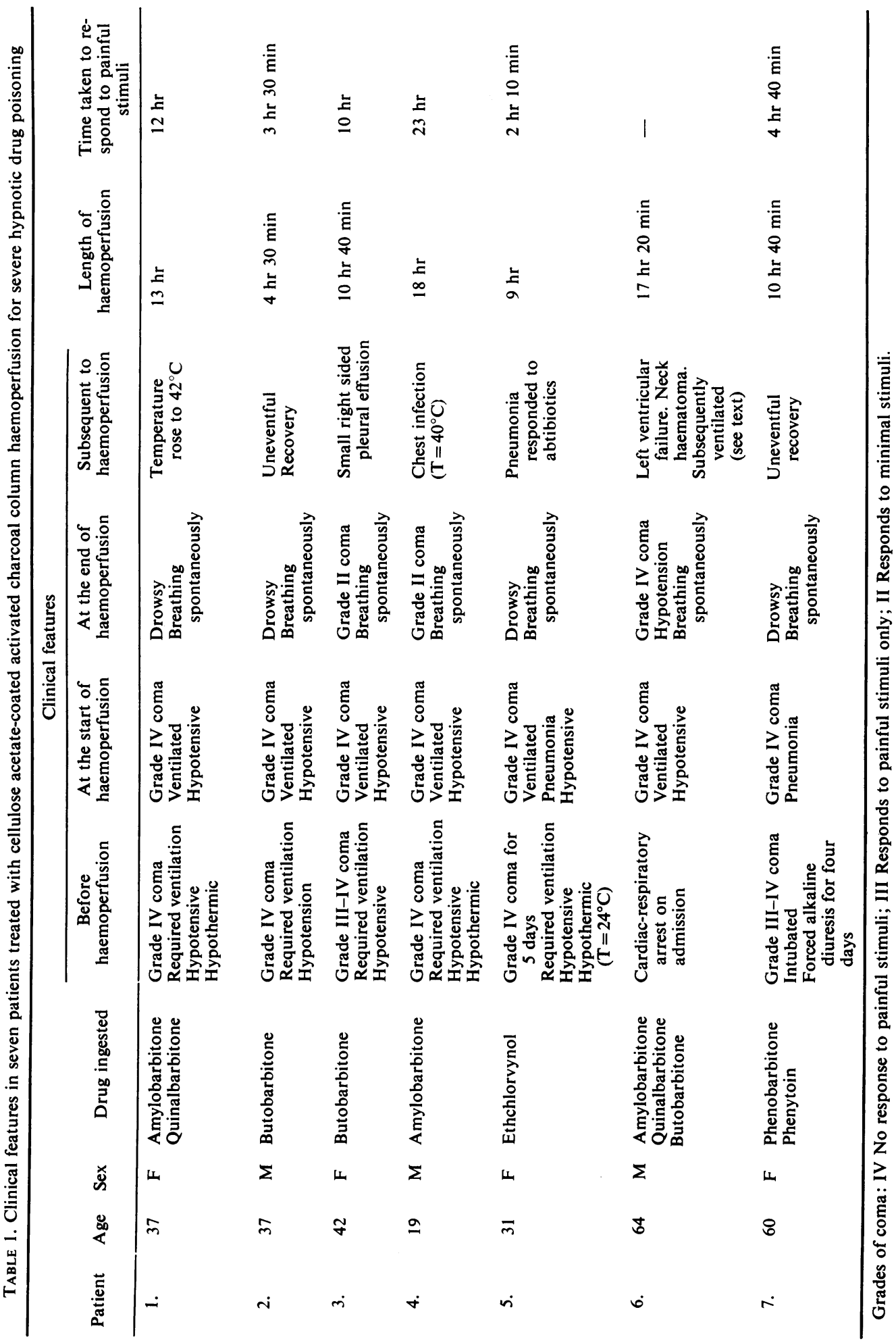


maintained except when this was prevented by hypotension. Haemoperfusion was continued until the pateint's level of coma had lightened significantly, or until plasma drug concentrations had fallen to low levels. Blood samples were taken before, during and after haemoperfusion for haematological, biochemical and toxicological investigations. All pateints were treated in an intensive care unit and received full supportive treatment.

Drug clearance was calculated from the formula:

$$
\text { Clearance }=\frac{\mathrm{C}_{\mathrm{A}}-\mathrm{C}_{\mathrm{v}}}{C_{\mathrm{A}}} \times \text { flow }(\mathrm{ml} / \mathrm{min}),
$$

where $C_{\mathrm{A}}$ and $C_{\mathrm{v}}$ are the drug concentration in the inlet and outlet plasma samples respectively. Flow was measured by a bubble-transit time technique.

The total amount of drug removed was calculated from the following formula derived by Winchester et al., (1975).

Amount removed,

$$
\frac{1}{2} \times(t y-t x) \times\left[\left(C_{1}-C_{2}\right)+\left(C_{3}-C_{4}\right)\right] \times F,
$$

where $t y-t x$ is the time interval; $C_{1}$ and $C_{2}$ are the inlet and outlet drug concentrations at time $t x ; C_{3}$ and $C_{4}$ are the corresponding values at time $t y ; F$ is the blood flow rate through the column.

\section{Results}

Seven patients were treated, 6 for barbiturate poisoning and one for the ethchlorvynol poisoning. Table 1 summarizes their clinical features.

The plasma drug concentrations at initial screening, at the start and end of haemoperfusion, together with the plasma clearance and the calculated total amount of drug removed are shown in Table 2. Six of the patients received a single haemoperfusion, whilst one received 2 treatments separated by $5 \mathrm{hr}$, the first using a cellulose acetate-coated column and the second an acrylic hydrogel-coated column. The cellulose acetate-coated column failed to lower the plasma drug concentration in this patient. This was probably a reflection of continued absorption of drug from the intestine or redistribution of drug from the tissues into the blood since the clearance data indicated that the drug was being removed at a somewhat faster rate than that achieved with the second column.

Platelet counts were performed in 5 of the 7 patients. The fall at 30 min after starting haemoperfusion ranged from 6.7 to $64.3 \%$ with a mean of $34.6 \%$. By the end of the procedure no platelet count was more than $30 \%$ below the pre-perfusion values.

Six of the 7 patients showed marked lightening of coma during this active treatment, the mean time taken to respond to painful stimuli being $9.2 \mathrm{hr}$ (range $2 \mathrm{hr} 10 \mathrm{~min}$ to $12 \mathrm{hr}$ ). Two of these patients recovered uneventfully, one had a small rightsided pleural effusion caused by a misplaced supraclavicular catheter inserted before haemoperfusion, and 2 other patients developed high temperatures. In one case this was associated with a severe chest infection, whilst in the other case there was no obvious cause of fever.

The 7th patient, who suffered a cardio-respiratory arrest on admission to hospital and before haemoperfusion had started, failed to regain consciousness despite a fall in total plasma barbiturate concentration from $51.6 \mathrm{mg} / 1$ to $19.5 \mathrm{mg} / \mathrm{l}$ after $17.5 \mathrm{hr}$ of treatment. The following day he began to respond to

\begin{tabular}{|c|c|c|c|c|c|c|c|c|c|}
\hline Patient & Drug & $\begin{array}{l}\quad \text { Plasma } \\
\text { At initial } \\
\text { screening }\end{array}$ & $\begin{array}{l}\text { drug concentra } \\
\text { At the start of } \\
\text { perfusion }\end{array}$ & \multirow{2}{*}{$\begin{array}{c}\text { tions }(\mathrm{mg} / \mathrm{l}) \\
\begin{array}{c}\text { At the end of } \\
\text { perfusion }\end{array} \\
3 \cdot 3 \\
4 \cdot 4\end{array}$} & \multirow{2}{*}{$\begin{array}{c}\begin{array}{c}\text { Blood flow } \\
(\mathrm{ml} / \mathrm{min})\end{array} \\
100-200\end{array}$} & \multicolumn{2}{|c|}{$\begin{array}{l}\text { Drug clearance } \\
(\mathrm{ml} / \mathrm{min})\end{array}$} & $\begin{array}{l}\text { Amount of } \\
\text { drug } \\
\text { removed (g) }\end{array}$ & $\begin{array}{l}\text { Length of } \\
\text { perfusion }\end{array}$ \\
\hline 1. $\mathrm{C}$ & $\begin{array}{l}\text { Quinalbarbitone } \\
\text { Amylobarbitone }\end{array}$ & $\begin{array}{l}20 \\
26\end{array}$ & $\begin{array}{l}24 \\
32 \cdot 5\end{array}$ & & & $\begin{array}{l}161 \\
166\end{array}$ & $\begin{array}{l}22 \\
35\end{array}$ & $\begin{array}{l}0.5 \\
0.7\end{array}$ & $13 \mathrm{hr}$ \\
\hline 2. B & Butobarbitone & 56 & 86 & 34 & $175-260$ & 155 & 71 & 1.6 & $4 \mathrm{hr} 30 \mathrm{~min}$ \\
\hline 3. $\mathrm{B}$ & Butobarbitone & 75 & 75 & 19 & 200 & 18.9 & 67 & $2 \cdot 9$ & $10 \mathrm{hr} 50 \mathrm{~min}$ \\
\hline 4.* A & Amylobarbitone & 59 & $\begin{array}{l}57 \cdot 6 \\
59\end{array}$ & $\begin{array}{l}59 \\
25 \cdot 5\end{array}$ & 200 & $\begin{array}{l}131 \\
100\end{array}$ & $\begin{array}{l}64 \\
40\end{array}$ & $\begin{array}{l}1 \cdot 4 \\
2 \cdot 7\end{array}$ & $\begin{array}{r}5 \mathrm{hr} \\
13 \mathrm{hr}\end{array}$ \\
\hline 5. $\mathrm{E}$ & Ethchlorvynol & 78 & 50 & 36 & 200 & 180 & 100 & $2 \cdot 4$ & $9 \mathrm{hr}$ \\
\hline 6. A & $\begin{array}{l}\text { Amylobarbitone } \\
\text { Quinalbarbitone } \\
\text { Butobarbitone }\end{array}$ & $\begin{array}{l}12 \\
25 \\
20\end{array}$ & $\begin{array}{l}13 \cdot 5 \\
19 \cdot 9 \\
18 \cdot 2\end{array}$ & $\begin{array}{l}7 \cdot 4 \\
8 \cdot 1 \\
3 \cdot 9\end{array}$ & 300 & $\begin{array}{l}144 \\
147 \\
213\end{array}$ & $\begin{array}{r}81 \\
110 \\
95\end{array}$ & $\begin{array}{l}0 \cdot 7 \\
0 \cdot 8 \\
1 \cdot 2\end{array}$ & $17 \mathrm{hr} 20 \mathrm{~min}$ \\
\hline 7. $\begin{array}{r}\mathrm{P} \\
\mathrm{P}\end{array}$ & $\begin{array}{l}\text { Phenobarbitone } \\
\text { Phenytoin }\end{array}$ & $\begin{array}{r}108 \\
24\end{array}$ & $\begin{array}{l}90 \\
40\end{array}$ & $\begin{array}{l}36 \\
27\end{array}$ & 150 & $\begin{array}{l}137 \\
105\end{array}$ & $\begin{array}{l}34 \\
10\end{array}$ & $\begin{array}{l}2 \cdot 2 \\
0 \cdot 6\end{array}$ & $10 \mathrm{hr} 40 \mathrm{~min}$ \\
\hline
\end{tabular}

TABLE 2. Plasma drug concentrations, drug clearances and total amount of drug removed

* This patient received 2 haemoperfusions, the second using an acrylic hydrogel-coated charcoal column. 
painful stimuli and his subsequent course was uneventful. None of the other patients had clinical complications attributable to haemoperfusion, or to anti-coagulation. Haemoperfusion was interrupted in the patient who received 2 treatments because of a defect in the extra-corporeal blood lines.

\section{Discussion}

Several charcoal haemoperfusion devices are now available commercially. These differ with regard to column design, the type and quantity of charcoal and the nature of the protective coating material. The performance of these devices must be judged on their ability to clear drugs from the circulation, their effects on the blood elements and their overall clinical safety. In all these respects, the cellulose acetate column was comparable to the devices which the authors have used previously.

Although there were no deaths in this series it would not be justified to compare these results directly with other series of similarly poisoned patients in whom there was a high mortality (Volans et al., 1977; Hampel and Widdop, 1978). The numbers in the present series were small and they were not matched for dosage of drug ingested and quality of supportive care. Nevertheless, the rapid lightening of coma seen in some patients strongly suggests that this technique might reduce morbidity.

The authors would advocate the use of haemoperfusion for severely poisoned patients who are either not responding or who are deteriorating despite receiving adequate intensive supportive care. The treatment is recommended for patients with prolonged coma and cardio-respiratory complica- tions provided that accurate toxicological analyses have revealed the presence of high plasma concentrations of an adsorbable drug. Although this technique is relatively simple it is always attended by the risk of haemorrhage and it is suggested that haemoperfusion should be carried out only in units equipped with the necessary toxicological and clinical facilities.

\section{References}

Hampel, G., Crome, P., Widdop, B. \& Goulding, R. (1980) Experience with fixed-bed charcoal haemoperfusion in the treatment of severe drug intoxication. Archiv für Toxikologie, 45, 133.

HAMPEL, G. \& Widdop, B. (1978) Experience with haemoperfusion in the treatment of acute drug intoxication. Proceedings of the European Society of Artificial Organs, 5, 202.

VAle, J.A., Rees, A.J., Widdop, B. \& Goulding, R. (1975a) Use of charcoal haemoperfusion in the management of severely poisoned patients. British Medical Journal, 1, 5.

Vale, J.A., Thomas, T., Widdop, B. \& Goulding, R. (1975b) Use of charcoal haemoperfusion in poisoned patients: a review of 20 cases. Proceedings of the European Society of Artificial Organs, 2, 239.

Volans, G.N., Vale, J.A., Crome, P., Widdop, B. \& GouldING, R. (1977) The role of charcoal haemoperfusion in the management of acute poisoning by drugs. In: Strathclyde Bioengineering Seminars-No 2-Artificial Organs. (Ed. by Kenedi, R.M. et al.) p. 178. The Macmillan Press, Londono and Basingstoke.

Winchester, J.F., Edwards, R.O., TILSTONE, W.J. \& Woodcock, B.G. (1975) Activated charcoal haemoperfusion and experimental acetaminophen poisoning.' Toxicology and Applied Pharmacology, 31, 120.

Yatzidis, H., Voudiclari, S., Oreopoulos, D., Tsaparas, N., Triantaphyllidis, D., Gavras, C. \& Stavroulaki, A. (1965) Treatment of severe barbiturate poisoning. Lancet, ii, 216. 